\title{
Pharmacognostic Study of Eranthemum nigrum Stem
}

\author{
DSNBK Prasanth* and A Lakshmana Rao \\ Department of Pharmacognosy, V. V. Institute of Pharmaceutical Sciences, India
}

Submission: April 20, 2018; Published: June 22, 2018

*Corresponding author: DSNBK Prasanth, Department of Pharmacognosy, V. V. Institute of Pharmaceutical Sciences, Seshadri Rao Knowledge Village, Gudlavalleru, India, Email: dsnbkprasanth@gmail.com

Abstract

Objective: To analyze the pharmacognostic characteristics and physiochemical parameters of the stem of Eranthemum nigrum [E. nigrum].

Methods: Microscopic characters and powder analysis had been carried out with the help of a microscope. The physiochemical properties such as loss on drying, total ash value, acid insoluble ash value, water soluble ash value, extractive values and fluorescence of E. nigrum had been performed.

Results: The color, shape, size, odor, and surface characteristics were reported from the stem and powdered stem material of E. nigrum. Light microscope images of cross section and powdered stem revealed the presence of Phloem fibers, Lignified Xylem Vessels, Lignified xylem fibers and Parenchyma cells. Phytochemical testing confirmed the presence of steroids, alkaloids, tannins, saponins, carbohydrates, glycosides, amino acids and proteins.. Physicochemical parameters such as moisture content, ash value, extractive value and fluorescent behavior of stem powder have also been established.

Conclusion: The current research would be useful in order to supplement the information regarding standardization, identity and in performing additional explorations in Ayurvedic system of medicine.

Keywords: Pharmacognostic; Eranthemum nigrum; Lignified xylem vessels; Phloem fibers; Phytochemical; Physicochemical analysis

\section{Introduction}

Medicinal plants are usually playing a significant part in traditional medicines intended for therapy of various health issues. However a crucial hurdle, which has impeded the promotion in the usage of alternative medications in the developed countries, is lack of evidence of documentation and absence of stringent quality control measures. Additionally, there is a dependence on the data of all study meted out on traditional medicines by way of documentation. Keeping this issue, it is now quite necessary to generate assurance about the standardization of the plant as well as its parts to be used like a medication. During the process of standardization, we are able to take advantage of various techniques and methodology to achieve our goal in a phase wise approach e.g. pharmacognostic and phytochemical studies. These techniques and methods are helpful in recognition and standardization of the plant material. Appropriate characterization and quality assurance of starting material is a crucial step to ensure reproducible quality of herbal medicine to assist people in order to justify its safety and effectiveness. Because of this reason, we have executed pharmacognostic studies of Eranthemum nigrum belongs to family Acanthaceae [1]. This sort of research is not going to help in authentication but additionally ensures reproducibility of herbal goods in promoting [2].
In the present study, we have been focusing our exploration on one of the commonly available plant in India i.e., Eranthemum nigrum, belongs to family Acanthaceae. The family Acanthaceae consists of almost 4000 species of exotic plants. Various species of Genus Eranthemum being utilized traditionally for extensive kinds of ethno medicinal purposes. The genus Eranthemum, with around 138 species, some of the important species include E. austrosinensis, E. burmanicum, E. capense, E. ciliatum, E. erythrochilum, E. griffithii, E. macrophyllum, E. macrostachyus, E. obovatum, E. pulchellum, E. purpurascens, E. roseum, E. strictum, E. tapingense, E. tubiflorum and E. watti. The Eranthemum nigrum [Acanthaceae] is native to Pacific Islands. The shrub attains height a height of $1.5-1.8 \mathrm{~m}$. The upper surface of leaves is blackish purple and the lower surface purplish with dark veins. The flowers are in terminal erect spikes, white and

spotted rose at the base [3]. Plants are adapted to partial shade. The leaves are elliptical, glossy or dull with smooth margins and acute tips [4,5]. All parts of this plant are widely used as a folklore medicine for the treatment of various ailments by the Indian traditional healer. Ethno medicinally, the genus Eranthemum has been documented various pharmacological activities including antipyretic [6], antidiabetic [7], antiulcer [8], antimicrobial [9], 
larvicidal, ovicidal and pupicidal against Anopheles stephensi [10], gastroprotective [11] and antiinflammatory [12].

A literature study and screening of scientific data says a lot of native medicines have already been investigated as regards their botany and chemistry is concerned, however a systematic standardization including Pharmacognostical and physicochemical study is still lacking. The present investigation of Eranthemum nigrum. [Acanthaceae] is therefore taken up to establish certain botanical and chemical standards which would help in crude drug identification as well as in checking adulteration, if any. Further, the study will greatly help in quality assurance of finished products of herbal drugs $[13,14]$.

\section{Materials and Methods}

\section{Plant collection and authentication}

The plant was obtained from V. V. Institute of Pharmaceutical Sciences, Gudlavalleru, Krishna district of Andhra Pradesh, India during the month of September 2017 and authenticated by Dr. K. Madhava Chetty, Taxonomist at Sri Venkateswara University Tirupati, India. The plant was deposited at the herbarium for future reference. One portion of the stem is preserved in formalin: acetic acid: alcohol mixture for histological studies and the remaining portion was shade dried, powdered and sieved through 20 mesh and kept in an air tight container for future use.

\section{Chemicals}

All analytical grade chemicals were utilized in this study were procured form E. Merck, Germany, absolute alcohol, phloroglucinol, acetic acid, chloral hydrate, $\mathrm{H}_{2} \mathrm{SO}_{4}, \mathrm{NaOH}, \mathrm{HNO}_{3}$, $\mathrm{FeCl}_{3}$, distilled water, Conc. $\mathrm{HCl}$ and chloroform.

\section{Pharmacognostic evaluation}

Morphological evaluation: Organoleptic evaluation of $E$. nigrum stem has been carried out in accordance the colour, size, odour, shape and taste as per WHO Quality Control methods of herbal medicine [15].

\section{Microscopic evaluation}

Preparation of sections: Microscopic studies had been done by preparing thin hand section of the stem with the help of sharp cutting edge of the blade, then cleared with chloral hydrate solution, stained with phloroglucinol-hydrochloric acid [1:1] and mounted in glycerin.

Powdered microscopy: The powder microscopy was carried out in accordance with the procedure described in Khandelwal [16].

Preparation of extracts and preliminary phytochemical analysis: The powdered material had been extracted with various solvents according to its polarity i.e., chloroform, methanol and water. $5 \mathrm{~g}$ stem powder was extracted with $20 \mathrm{ml}$ of the respective solvent by maceration at room temperature for 24 hours. Then, filtered through whatmann filter paper and collect the filtrate, concentrated with rota-evaporator. Then, the extracts had been subjected to preliminary phytochemical screening according to standard methods $[16,17]$.

Physicochemical analysis: Physicochemical parameters such as ash value, moisture content and extractive values were determined according to the procedures mentioned in WHO quality control methods for herbal materials [18].

Fluorescence analysis: Various reagents were utilized to check the fluorescence activity. In this, $0.1 \mathrm{~g}$ of stem powder was blended with $1.5 \mathrm{ml}$ of respective reagent (Table 4). The mixture was placed on slide for a minute and observed under visible light, short ultra-violet light [254nm] and long ultraviolet light [365nm] [19].

\section{Results}

\section{Morphological characteristics}

The morphological characteristics of E. nigrum stem were described in (Figure 1) \& (Table 1).

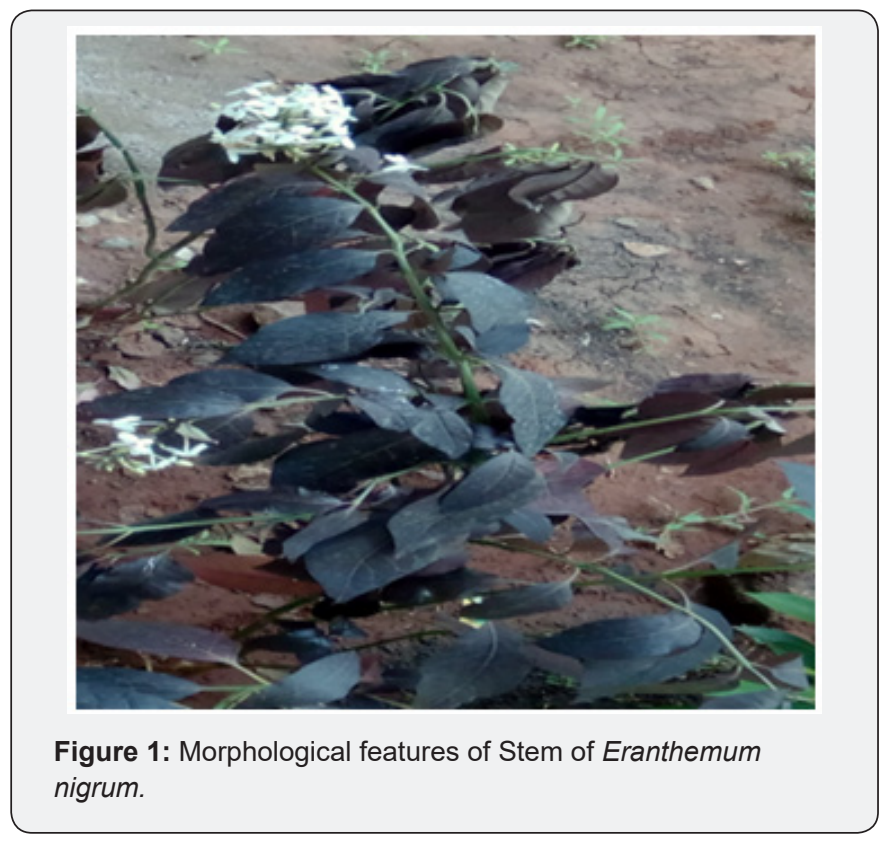

Table 1: Morphological characteristics of stem of eranthemum nigrum

\begin{tabular}{|c|c|}
\hline Characters & Observation \\
\hline Colour & Green \\
\hline Odour & Characteristic \\
\hline Taste & Characteristic \\
\hline Texture & Smooth \\
\hline
\end{tabular}

\section{Anatomical description}

Stem: Transverse [TS] section of stem showed barrel shaped cells constituting the epidermis, which was arranged compactly without intercellular spaces with multicellular uniseriate covering trichomes. The hypodermis was composed of collenchyma cells, which were arranged in 5-6 layered, provided additional protection and support. It was followed by parenchymatous cells arranged in 6-7 layers. Vascular bundles were conjoint, collateral and open. 
Xylem was present in the continuous ring consisting of vessels, portion is occupied by parenchymatous cells as shown in (Figure fibers, and xylem parenchyma. Phloem consisted of phloem fibers, 2-4).

sieve cells, companion cells and phloem parenchyma. The central

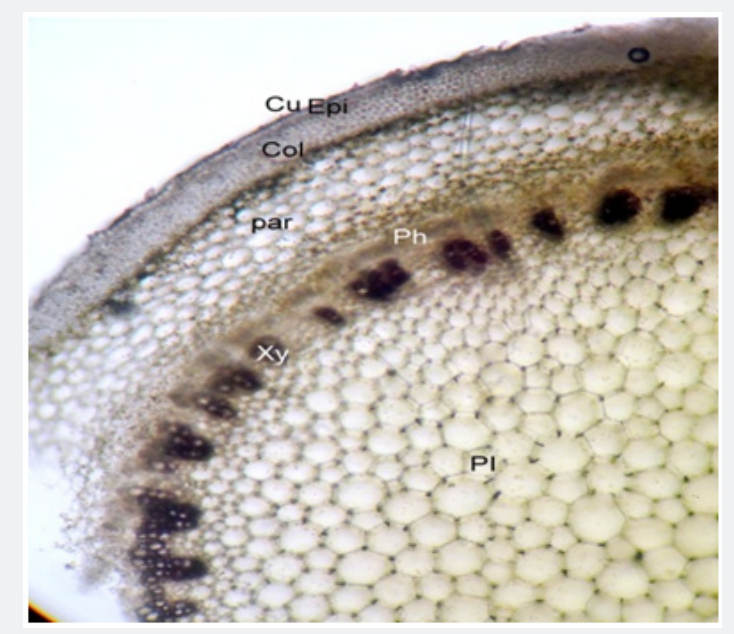

Figure 2: Transverse section of stem of Eranthemum nigrum. Cu: Cuticle; Epi: Epidermis; Col: Collenchyma; Par: Parenchyma; Xy: Xylem; Ph: Phloem and PI: Pith.

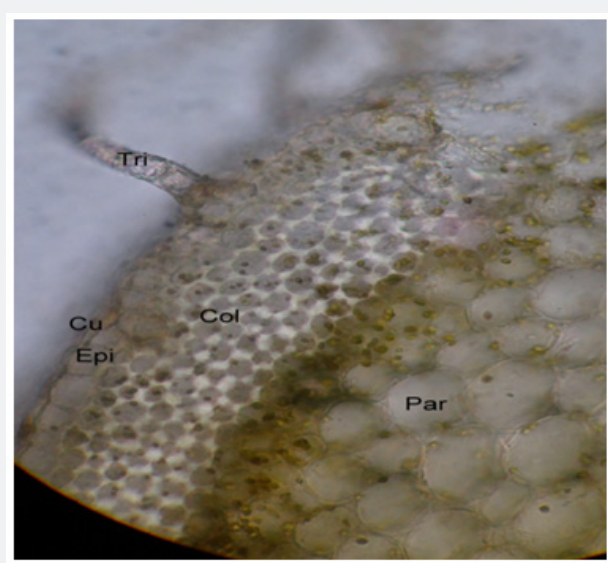

Figure 3: Detailed T.S of Stem showed upper epidermis, collenchyma and parenchymatous cells of Eranthemum nigrum. Tri: Trichome; Cu: Cuticle; Epi: Upper Epidermis; Col: Collenchyma cells; Par: Parenchyma cells.

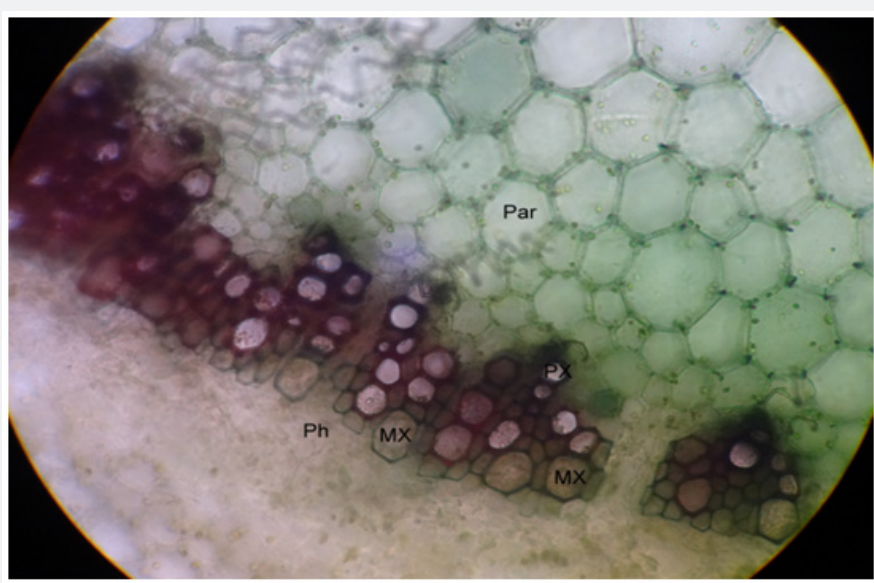

Figure 4: T.S of Stem of Eranthemum nigrum showed Vascular Bundles Ph: Phloem; MX: Metaxylem; PX: Protoxylem; Par: Parenchyma cells. 


\section{Current Trends in Biomedical Engineering \& Biosciences}

Powder microscopy: The crude powder of stem was buff in color with characteristic odor and taste. Microscopic study of the powder showed revealed different characters such as
Phloem fibers, Lignified Xylem Vessels, Lignified xylem fibers and Parenchyma cells (Figure 5).
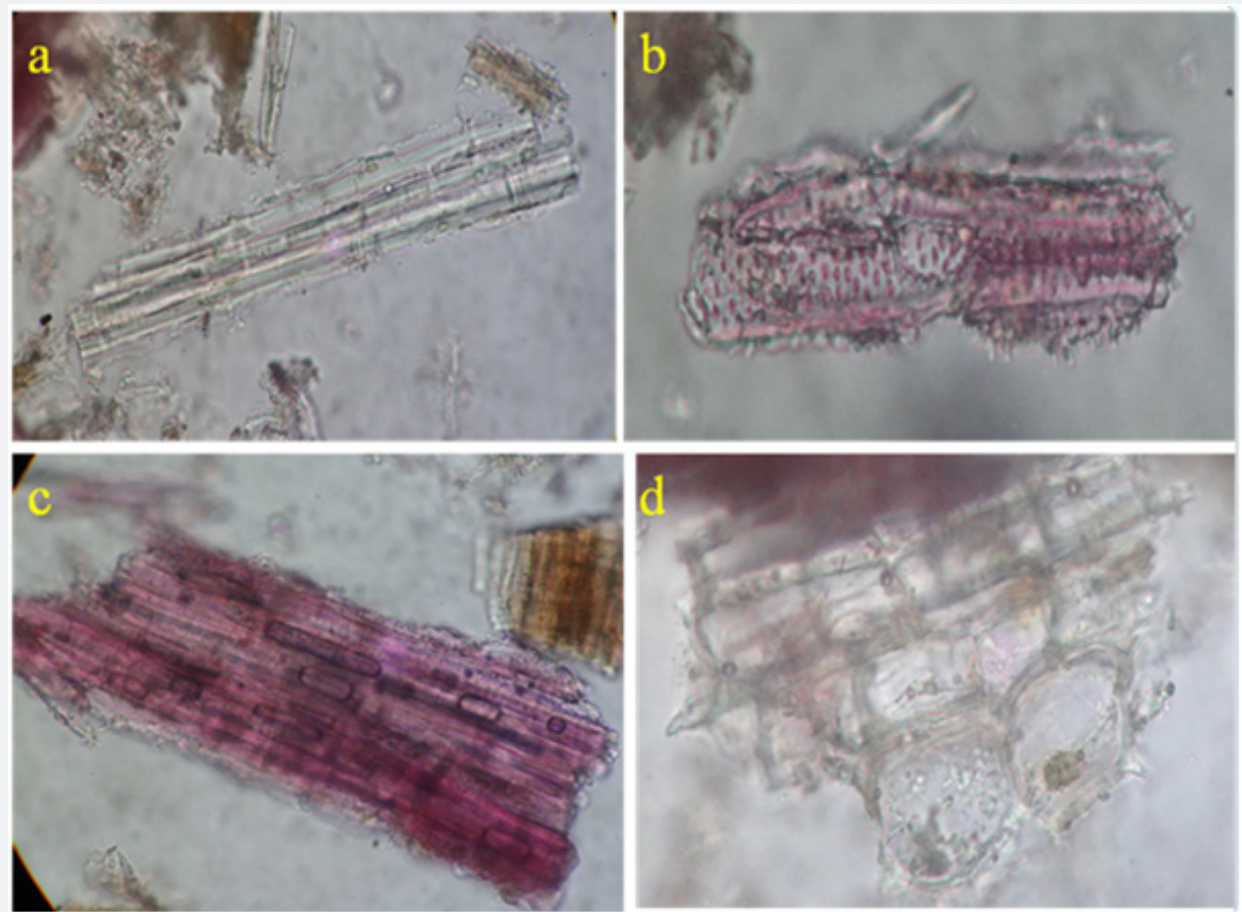

Figure 5: Powder microscopy of stem of eranthemum nigrum (a) Phloem fiber (b) Lignified xylem vessel (c) Lignified xylem fiber (d) Parenchyma cells.

Preliminary phytochemical analysis: The results of Stem were shown in Table 2. qualitative phytochemical analysis of crude powder of E. nigrum

Table 2: Preliminary Phytochemical analysis of Eranthemum nigrum stem.

\begin{tabular}{|c|c|c|c|c|c|}
\hline Phytoconstituents & Method & Aqueous Extract & Methanolic Extract & Chloroform Extract & Pet. Ether Extract \\
\hline \multirow[t]{3}{*}{ Flavonoids } & Shinoda Test & - & - & - & - \\
\hline & Zn. Hydrocholride test & + & + & - & - \\
\hline & Lead acetate Test & + & + & - & - \\
\hline Volatile oil & Stain test & - & - & - & - \\
\hline \multirow[t]{2}{*}{ Alkaloids } & Wagner Test & + & + & + & - \\
\hline & Hager's Test & + & + & + & - \\
\hline \multirow[t]{2}{*}{ Tannins \& Phenols } & Fecl3 Test & - & - & - & - \\
\hline & $\begin{array}{c}\text { Potassium dichromate } \\
\text { test }\end{array}$ & - & - & - & - \\
\hline Saponins & Foaming Test & + & + & - & - \\
\hline $\begin{array}{c}\text { Steroids \& } \\
\text { Triterpenoids }\end{array}$ & Salkowski test & + & + & - & + \\
\hline Carbohydrates & Molish test & + & + & - & - \\
\hline Acid compounds & Litmus test & - & - & - & - \\
\hline Glycoside & Keller-Killani Test & + & + & - & - \\
\hline Amino acids & Ninhydrin test & + & + & - & - \\
\hline Proteins & Biuret & + & + & - & - \\
\hline
\end{tabular}

“+"-Present "-" -Absent 
Physicochemical parameters: The results attained from various determinations of physicochemical analysis are produced in Table 3.

Table 3: Physicochemical parameters of stem powder of eranthemum nigrum.

\begin{tabular}{|c|c|}
\hline Parameters & Values $\% \mathbf{w} / \mathbf{w}$ \\
\hline Moisture content (Loss on drying) & $5.58 \pm 0.87$ \\
\hline Total ash & $6.54 \pm 1.63$ \\
\hline Acid insoluble ash & $1.75 \pm 0.76$ \\
\hline Petroleum ether soluble extractive value & $0.48 \pm 0.05$ \\
\hline Chloroform soluble extractive value & $0.83 \pm 0.05$ \\
\hline Ethyl acetate soluble extractive value & $3.52 \pm 0.08$ \\
\hline Alcohol soluble extractive value & $8.63 \pm 0.22$ \\
\hline Water soluble extractive value & $9.45 \pm 0.23$ \\
\hline
\end{tabular}

Fluorescence analysis: Fluorescence analysis of stem powder was performed out after treating with different solvents. Fluorescence was observed at 254 and $365 \mathrm{~nm}$ comparing its change of color in the visible light. The observations are presented in Table 4 shows the variation in color.

Table 4: Fluorescence analysis of Eranthemum nigrum stem powder.

\begin{tabular}{|c|c|c|c|}
\hline Solvent Used & Visible Light & UV Light & \\
\hline & & $\begin{array}{l}\text { At Short } \\
(254 \mathrm{~nm})\end{array}$ & $\begin{array}{c}\text { At Long } \\
(365 \mathrm{~nm})\end{array}$ \\
\hline Distilled water & Pale Green & Black & Black \\
\hline Methanol & Green & Black & Greyish white \\
\hline $1 \mathrm{~N} \mathrm{HCl}$ & Green & Black & Black \\
\hline $50 \%$ HNO3 & Red & Black & $\begin{array}{c}\text { Fluorescent } \\
\text { Green }\end{array}$ \\
\hline $\mathrm{FeCl} 3$ & Orange & Dark blue & Black \\
\hline $\mathrm{CHCl} 3$ & Pale green & Brown & Black \\
\hline Picric acid & Yellowish green & Dark blue & Black \\
\hline Ethyl acetate & Green & Black & Greyish white \\
\hline
\end{tabular}

\section{Discussion}

Indian systems of medicine utilize majority of the crude drugs which are of plant origin. It is important that standards need to be set down to control and check the identity of the plant and confirm its quality before use. Hence a detailed pharmacognostic assessment is extremely an important prerequisite. In accordance with World Health Organization [WHO] the organoleptic and histological description of a medicinal plant could be the first step towards establishing its identity and purity and should be performed before to any tests tend to be undertaken [20].

E. nigrum, extensively utilized in conventional medicines has tremendous therapeutically potential due to its various biological activities. The prominent diagnostic characteristics of stem were Phloem fibers, Lignified Xylem Vessels, Lignified xylem fibers and Parenchyma cells. These characters can be utilized for standardization of drugs as well as useful for preparation of plant monograph and also reduces the possibilities of adulteration, when the drug is available in the powdered form studies of physicochemical parameters can serve as an important source to judge the purity and quality of crude drugs. Ash values are utilized to establish the quality and purity of the crude drug. It implies the existence of various impurities like carbonate, oxalate and silicate. The water soluble ash is water soluble part of total ash, employed to calculate the amount of inorganic substances found in the drugs. The acid insoluble ash comprises mostly silica and indicates contamination with earthy matter. The moisture content of drugs might be at minimum level in order to suppress the growth of microorganisms like bacteria, yeast or fungi during storage. The extractive values are helpful to judge the chemical constituents present in the crude drug and also assist in the evaluation of particular constituents soluble in a specific solvent. Total ash and acid insoluble ash are essential indices to illustrate the quality and purity of the herbal medicine. Total ash consists of physiological ash, which is derived from plant tissue itself, and nonphysiological ash that is usually from atmosphere contaminations includes sand and soil. Total ash content alone is not adequate to indicate the quality of herbal medicine, because the plant materials usually contain a significant level of physiological ash, calcium oxalate in particular. Therefore, the acid insoluble ash content is another index to indicate the quality of herbal medicine [21]. The phytochemical analysis of extracts viz., petroleum ether, chloroform, methanol and water were analyzed and it indicates the presence of steroids, alkaloids, tannins, saponins, carbohydrates, glycosides, amino acids and proteins.

\section{Conclusion}

Standardization of herbal drugs is very much crucial because they are produced from heterogeneous sources which could result in variations. These kinds of variations can cause spurious results in various pharmacological and phytochemical studies. Eranthemum nigrum stem is recognized for many therapeutical properties, therefore, the current study might be beneficial to supplement the information in respective to its identification, authentication, and standardization; no such information is available for the same till date.

\section{References}

1. Akbar S, Hanif U, Ali J, Ishtiaq S (2014) Pharmacognostic studies of stem, roots and leaves of Malva parviflora L. Asian Pac J Trop Biomed 4(5): 410-415.

2. Amponsah IK, Mensah AY, Otoo A, Mensah MLK, Jonathan J (2014) Pharmacognostic standardisation of Hilleria latifolia (Lam.) H. Walt. (Phytolaccaceae). Asian Pac J Trop Biomed 4(12): 941-946.

3. Randhawa GS, Mukhopadhyay A (2004) Floriculture in India. New Delhi, India.

4. Thekkayam SG, Peter KV (2009) Ornamental plants. New India Pub Agency, New Delhi, India.

5. Ona NJ (2007) Foliage :astonishing color and texture beyond flowers North Adams, Storey Publishing, Massachusetts, USA, p. 571.

6. Samvatsar S, Diwanji V (2004) Plants used for the treatment of different types of fevers by Bhils and its subtribes in India. Ind J Traditional Knowledge 3(1): 96-100. 
7. Dhruv D, Anil T, Sanjay S, Sapna D (2010) Antidiabetic and antioxidant properties of roots of Eranthemum roseum vahl r. br. Inventi Rapid: Ethnopharmacology.

8. Kamble S, Patil S, Sawant P, Sawant S, Pawar S, et al. (2010) Studies on plants used in traditional medicine by Bhilla tribe of Maharashtra. Indian Journal Of Traditional Knowledge 9(3): 591-598.

9. Jain A, Surana S, Gokhale S, Tatiya A, Bothara R (2010) Antimicrobial Properties of Eranthemum roseum (Vahl) R. Br IJPR 6(2): 131-133.

10. Milne-Redhead E (1936) ranthemum of the "Flora of Tropical Africa". Bulletin of Miscellaneous Information (Royal Botanic Gardens, Kew) 1936(4): 255-274.

11. Patil P, Surana S (2009) Gastroprotective effect of Eranthemum roseum R. Br. Linn Root extracts in albino rats. Int J Pharmacol Biol Sci 3(1) 81-93.

12. Tatiya A, Desai D, Surana S, Patil P (2007) Anti inflammatory and nitric oxide scavenging activity of roots of Eranthemum roseum. Indian Drugs 44(11): 815-818.

13. Jhade D, Ahirwar D, Jain R, Sharma N, Gupta S (2011) Pharmacognostic standardization, physico-and phytochemical evaluation of Amaranthus spinosus linn. Root. J Young Pharm 3(3): 221-225.
14. Ghorpade P, Siddiqui A, Patil MJ, Rub RA (2012) Pharmacognostic and phytochemical evaluation of Celosia argentea. Phcog J 4(33): 7-15.

15. World Health O (2011) Quality control methods for herbal materials Geneva: World Health Organization, Geneva, Switzerland.

16. Khandelwal KR (2008) Practical pharmacognosy: techniques and experiments. Maharashtra: Niral Prakashan, Pune, India.

17. Harborne AJ (1998) Phytochemical methods a guide to modern techniques of plant analysis. springer science $\&$ business media, Berlin, Germany.

18. Galani VJ, Patel BG (2011) Psychotropic activity of Argyreia speciosa roots in experimental animals. Ayu 32(3): 380-384.

19. Dave R, Nagani K, Chanda S (2010) Pharmacognostic Studies and Physicochemical Properties of the Polyalthia longifolia var. pendula Leaf. Phcog J 2(13): 572-576.

20. Vaghasiya Y, Nair R, Chanda S (2008) Antibacterial and preliminary phytochemical and physico-chemical analysis of Eucalyptus citriodora Hk leaf. Nat Prod Res 22(9): 754-762.

21. Prasanth D, Rao AS, Yejella RP (2016) Assessment of pharmacognostic phytochemical and physicochemical standards of Aralia racemosa (L.) root. Ind J Pharm Edu Res 50(3): S225-S230.

\begin{tabular}{|l|}
\hline \multicolumn{1}{|c|}{ Your next submission with Juniper Publishers } \\
will reach you the below assets \\
- Quality Editorial service \\
- Swift Peer Review \\
- Reprints availability \\
- E-prints Service \\
- Manuscript Podcast for convenient understanding \\
- Global attainment for your research \\
- Manuscript accessibility in different formats \\
( Pdf, E-pub, Full Text, Audio) \\
- Unceasing customer service \\
Track the below URL for one-step submission \\
https://juniperpublishers.com/online-submission.php
\end{tabular}

